\title{
THE IDEA OF COMMERCIAL SOCIETY IN THE SCOTTISH ENLIGHTENMENT
}





\section{THE IDEA OF \\ COMMERCIAL SOCIETY IN THE SCOTTISH ENLIGHTENMENT \\ Christopher J. Berry}


(C) Christopher J. Berry, 20I 3

Edinburgh University Press Ltd 22 George Square, Edinburgh EH8 9LF

www.euppublishing.com

Typeset in Sabon by

Servis Filmsetting Ltd, Stockport, Cheshire, and printed and bound in Great Britain by CPI Group (UK) Ltd, Croydon CRo 4 YY

A CIP record for this book is available from the British Library

ISBN $978 \circ 748645329$ (hardback)

ISBN $978 \circ 748645336$ (webready PDF)

ISBN $978 \circ 748684533$ (epub)

The right of Christopher J. Berry

to be identified as author of this work

has been asserted in accordance with

the Copyright, Designs and Patents Act I988. 